\title{
Canvia la tecnologia o també canvia el pensament? Indicis de com es transforma la comunicació folklòrica en el trànsit als comportaments tecnològics
}

\author{
Jaume Ayats i Abeyà \\ Universitat Autònoma de Barcelona \\ Museu de la Música de Barcelona \\ jayatsa@bcn.cat
}

\begin{abstract}
RESUM
Si partim de la consideració de folklore com un acte comunicatiu i interrelacional, en el context de la societat que ens envolta no podrem evitar abordar la transformació, probablement ben profunda, que s'està produint en les interaccions comunicatives: es transformen les tecnologies que fem servir contínuament $i$, amb elles, canvien els comportaments de les persones pel que fa a l'ús de la tecnologia.
\end{abstract}

PARAUles CLAU

folklore; comunicació; tecnologia; societat; ús

\section{ABSTRACT}

Tracking the status of folklore as a communicative and interelacional act, in the context of the society that surrounds us we cannot avoid addressing the transformation, probably very deep, that is taking place in communicative interactions: we transform technologies served continuously and with them, changing behaviours of individuals in relation to the use of technology.

KEYWORDS

folklore; communication; technology; society; use 
RECORDEM, en una brevíssima síntesi de les cinc característiques que ha de complir la comunicació folklòrica, la proposta de Dan Ben-Amos i l'adopció que en va fer des de Catalunya Josep Maria Pujol: ${ }^{\text {I }}$

I. Artistic action / Configurat artísticament

2. Face to face, Social interaction / En contacte directe (interactivament)

3. In small group / Dues o més persones, cara a cara

4. Communicative process / Comunicació especial, entre individus que comparteixen un sistema de signes

5. Per superar situacions difícils, delicades o potencialment conflictives

I des d'aquests cinc punts entendrem — per fer-los més abastables i acostar-los a la nostra visió- que:

I. La configuració artística, per tal de separar-la de la noció art construïda des dels idealismes europeus dels dos darrers segles, la situarem com l'acte de recórrer a formalitzacions que els interlocutors tenen a l'abast. A l'abast des del saber previ en què estan enculturats i que comparteixen en bona manera. $\mathrm{O}$, dit des d'un altre angle: es tracta sempre de citacions. De citacions des de la possibilitat d'un continu reciclatge i des de la possibilitat de mescles i combinacions de les fórmules citades. Per tant, l'experiència en l'activitat i la memòria són decisives en aquest punt. I, per tant, es converteix en decisiva la transformació de l'experiència i, especialment, de la memòria que fem des de la tecnologia.

2 i 3 . El contacte directe, el cara a cara, i la interacció en grup reduït són probablement els punts de la relació comunicativa que de seguida acceptem que estan afectats per la transformació tecnològica.

4. La forma especial de la comunicació folklòrica i el fet de compartir un sistema de signes ens retorna a la idea de citacions i de reciclatge des d'un codi compartit que hem esmentat en el punt $\mathrm{I}$.

5. Finalment, el darrer punt vol abordar el perquè de la comunicació folklòrica. Probablement és la característica que obre més camp de debat i de matisos, i que és més difícilment aferrable (tot i que, decididament, la més important). De seguida ens duu a considerar la globalitat de la comunicació humana i, si no ens aturem, ens duria fins al punt d'haver d'avaluar el perquè de les societats i de la vida personal. És ben clar que no tenim capacitat de parlar-ne ara i aquí. I, ni que sigui com a hipòtesi de

I. Per a aquesta síntesi, ens hem beneficiat del treball d'Ignasi Roviró (I992). 
treball, podem considerar que, pel que fa als canvis tecnològics en l'aproximació que proposem avui, és la que condiciona menys.

Partint d'aquest esquema, doncs, proposarem algunes observacions preliminars i una avaluació d'indicis que ens poden orientar de cap on es dirigeix la transformació de la comunicació folklòrica en l'actual trànsit a nous comportaments en l'ús de les tecnologies.

\section{Del cara a cara a la interacció d'individus en xarxa}

El model de referència de la comunicació folklòrica és la reunió en un espai definit d'un petit grup de persones en una interacció cara a cara. És des d'aquesta imatge - fins a cert punt ideal- que durant dècades hem treballat el procés comunicatiu i els missatges, tot i les repetides crides a imaginar «perifèries» on intervenen des de les fotocòpies fins al telèfon i des de l'acció comunicativa solitària fins a la premsa escrita.

A hores d'ara ja tenim clar que la interacció tecnològica que fins ara hi intervenia en forma de crear un «grup espectador» (cinema, ràdio, televisió o equip d'alta fidelitat) ha esclatat ja fa una estona en artefactes decididament més interactius. Des de l'aparició del correu electrònic, les possibilitats s'han acumulat fins al Whatsapp, l'Skype i les aplis. I en tots els casos la «xarxa» vol fer interactuar amb les característiques del petit grup cara a cara, però ho fa amb unes característiques que, al meu entendre, desplacen i conformen la interacció amb diverses configuracions que cal avaluar. Arrisquem-ne, en una observació superficial, unes quantes.

El «cara a cara» mitjançat per la tecnologia presenta unes circumstàncies singulars que el fan notablement diferent del «cara a cara» físic. De tal manera que l'estudi de la interacció des de les eines ja clàssiques d'Erwin Goffmann (I967) necessitaran una revisió profunda: la consideració de què són els frames, el «perdre la cara», i bona part de les construccions del diàleg queden alterats, d'una banda, per la no-visió (total o parcial) dels interlocutors; segonament, pel desplaçament temporal (breu o llarg) de la interacció, i, en tercer lloc, per l'ús d'artefactes escripturals cada vegada més sofisticadament codificats (des d'emoticones fins a expressions-cita o fins a ortografies metasignificatives) que construeixen els marcs de relació possible i que en fan una narrativa de formalització molt determinada i d'una significació que jo considero opaca (i, per tant, molt més polisèmica del que pensem d'entrada). I aquestes interaccions crec que cada vegada estan més lligades a les experiències singulars de grups que modulen el «cara a cara» lingüístic directe sense possibilitat de discontinuïtat amb les interaccions telemàtiques. Una banda i l'altra passen a ser, d'alguna manera, la mateixa cosa, fins al punt que potser un gest facial pot llegir-se des de la senyalística d'una emoticona. Som en el zàping d'estar simultàniament en dos (o tres o quatre) nivells de petit grup en el mateix moment. I això que és fatigós per a la generació que ja tenim unes quantes dècades a l'esquena, és obvi i «naturalitzat» per a les generacions joves. Només la possibilitat de sentir la música enregistrada desitjada aplicant-la a l'instant a qualsevol lloc i espai és una revolució en la percepció de l'espai/temps que probablement té unes dimensions que encara no hem sabut avaluar correctament. 
Coordenades de temps i espai amb delay, realitat física barrejada amb codis de diferents nivells (oral, escrit, visual, sonor) que es combinen sense discontinuïtat... No cal ser un especialista de les tecnologies i de la percepció (i sense entrar en la trampa comercial d'una suposada «realitat virtual») per entendre que només som al principi d'uns canvis més profunds del que possiblement pensàvem. Potser la interacció quotidiana entre humans i també amb la realitat de l'entorn se'ns transforma més del que en som conscients. I encara més si observem l'alta intensitat d'hores i d'emocions que moltes persones estan dedicant a aquesta mena de comunicacions, en un creixement fins ara imparable.

\section{De les citacions i els reciclatges}

La transformació del punt precedent afecta, també, el mecanisme de la citació constant i del reciclatge. Si en la comunicació folklòrica fins ara ens fixàvem sobretot en els codis verbals —i especialment en la narració oral—, segurament ara hem d'enfrontar-nos a un entramat de codis constantment interconnectats. I la dificultat que ja teníem en l'avaluació dels gestos, dels sons no estrictament lingüístics (o també dels lingüístics suprasegmentals i d'aquells més codificats que hem convingut a denominar música), ara es veu ampliada amb signes d'ordre més divers, i elaborats uns des de disposicions preconstruïdes pels dissenyadors tecnològics i altres, en canvi, més lliures i, sobretot, molt més nombrosos. Tots en unes progressions geomètriques que creen una mar de possibilitats fins ara inimaginable. L'art de la citació es transforma, doncs, en tota una altra cosa i desenvolupa unes habilitats possiblement noves: les habilitats creatives de cadascú probablement hi passen a tenir un paper més decisiu.

Si la citació i el reciclatge ja eren la base indiscutible de l'oralitat i de la creació, però dins d'uns codis socials flexibles, altament compartits i altament coneguts per tots els participants (gairebé mai fora d'un codi lingüístic mínimament compartit, per exemple), ara el terreny és un altre. Els interlocutors poden tenir molt menys espai compartit (i l'estan recreant d'una manera menys flexible en la conformació de la fórmula, però ho fan molt més ràpidament a cada interacció) al mateix temps que tenen moltíssims més recursos de citació a disposició (tants que «s'hi poden perdre»). El marc lingüístic, en canvi, és probablement més feble, com deduïm que passa amb l'ús d'una escarransida lingua franca anglesa entre un català i un japonès que, malgrat això, poden arribar a construir una interacció folklòrica d'alta intensitat, almenys en alguns aspectes.

Si fem cas de certs punts de vista, podríem pensar en una disminució d'una suposada «qualitat» de comunicació folklòrica per l'afebliment del marc referencial comú. I ho podríem exemplificar, per exemple, en la disminució de les habilitats de reciclatge/recreació que tenia un glosador antic. Però res no ens permet descartar que hi hagi altres eixos de «qualitat» que, a causa de l'angle de perspectiva on estem situats, probablement s'escapen de la nostra anàlisi. 


\section{Noves formes de memòria: de la memòria interna i les memòries externes}

Ara bé, la transformació al meu entendre més amagada és la que s'està produint en la memòria (i que probablement només afecta, encara, una proporció ben petita dels humans actuals). Jack Goody (I986) ja va mostrar com l'escriptura (i, de manera més precisa, diverses maneres d'escriptura) va anar configurant amb els segles unes lògiques d'estructuració del pensament, de la memòria i de l'organització social que, fins a cert punt, amplien o modifiquen les lògiques i la memòria dels individus i de les societats àgrafes. Els que hem tingut l'ocasió de treballar en entorns amb individus «no afectats» per la lògica de l'escriptura, hem observat alguns elements d'aquestes divergències. Hem comprovat que en general tenen molta més memòria — si l'han exercitada- les persones àgrafes que no les llegides. I que certs procediments narratius estan molt més desenvolupats en l'oralitat sense escriptura que no pas en l'oralitat que es recolza en la grafia de l'escriptura.

Com afecten els artefactes tecnològics en la memòria de l'individu? Els exemples musicals ens indiquen la magnitud de la transformació. La possibilitat d'escoltar exactament el mateix enregistrament sonor tantes vegades com vulguis i en qualsevol dels llocs habitables és un fet que trasbalsa totes les condicions precedents de la percepció sonora, i que transforma la memòria d'arrel. En l'oralitat directa, el missatge sonor s'ha d'adequar de manera necessària al lloc, a la situació i als interlocutors. L'oralitat mitjançada per la reproductabilitat tecnològica, en canvi, pot ser la repetició estrictament exacta d'uns sons. Els procediments d'adaptació, els marges de realització, els codis flexibles, tot el codi comunicatiu, en definitiva, queda traslladat. I la imaginació de «l'obra» es transforma, per primera vegada en la història, en una realitat acústicament objectivable que ens fa creure en «l'objecte musical», o sigui, en aquest monstre absurd, si el considerem des de la interacció comunicativa clàssica.

L'individu, per tant, ja té una referència exacta que pot activar, i no pas una apropiació imaginada amb uns notables marges de flexibilitat. Si les possibilitats del reciclatge i dels recursos — dèiem - han crescut geomètricament, els marges d'aquesta flexibilitat estan disminuint. I la memòria de l'activitat es transforma fins al punt de poder-nos desagradar i destorbar profundament la interpretació d'un cantant que venerem amb devoció, però que només venerem en la versió que va enregistrar en un moment concret, i que ha quedat repicada en el cervell a força d'escoltar-la centenars de vegades.

Una sorpresa. En el treball d'un estudiant de màster sobre l'ús de l'iPod d'un grup d'adolescents, descobrim que les cançons que aquests joves tenen en ús des de l'artefacte tecnològic són unes I2O (l'artefacte en conserva moltes més, però el nivell d'ús i de coneixement de la resta és molt menys rellevant que les de la xifra esmentada). Els bons cantadors de balades del nord de Catalunya que hem pogut conèixer (i que no començaven mai a cantar una cançó si no estaven segurs d'acabar-la) tenien en ús un nombre molt semblant de cançons. D'aquí que m'atreveixi a plantejar fins a quin punt no hem de considerar la «memòria externa» i la «memòria interna» com dues adequacions de la mateixa funció. Els adolescents, això sí, varien amb una certa rapidesa el nucli de cançons en ús, mentre que la capacitat de substitució de les cançons dels vells baladistes, segons deduïm, devia ser molt menys ràpida. Perquè, quan sentim les cançons en l'artefacte de memòria 
externa, fins a quin punt n'estem escoltant els detalls sonors? O potser l'artefacte és només un medi per activar la nostra memòria interna? Podria ser que en el fons escoltéssim més l'ideal que ja tenim emmagatzemat dins del cervell que no pas les ones acústiques que ens arriben físicament. O sigui, potser sentim més allò que ja sabem que no pas escoltem els detalls de la percepció física. Seria interessant pensar els artefactes d'acumulació de continguts com un pretext per guanyar el temps necessari perquè la nostra memòria revisqui en l'hic et nunc allò que ja tenim en la «memòria interna» (si més no, li ho tenim parcialment, guiant-la en les estructures que ja no cal que la memòria interna s'esforci a recordar).

En tot cas, penso que estarem d'acord que la transformació de la memòria i de la percepció és fonamental en les interaccions de comunicacions folklòriques. No podem pensar en el missatge sense tenir en compte com el missatge és percebut i com és recordat per a reutilitzacions posteriors.

\section{Els canvis en el pensament i la memòria: canviem neuronalment?}

I acabaré aquesta aproximació superficial precisament amb la percepció. Els neuròlegs ja ens han informat, en els darrers anys, que la percepció no es rep, sinó que es construeix. Però potser encara han d'insistir més en el fet que el treball d'apropiació de la percepció també construeix. La plasticitat de les connexions neuronals fa que el nostre treball de percepció les transformi. Si l'escriptura ha anat canviant la lògica i el discurs és perquè també ha modificat certes comunicacions neuronals i ha entrenat unes habilitats precises, fent-les més ràpides i sofisticades.

Ara, amb els nous artefactes, pot ser que siguem a l'inici d'un canvi molt més profund? No en sabem la resposta, però molt probablement és positiva. L'individu del futur serà amb una memòria diferent, amb molta col-laboració de la tecnologia externa? Plantejar aquestes qüestions pot ser ben arriscat. I pot provocar rebuig o por. Però, si som una mica curiosos i rigorosos en la recerca, és precisament en la vida quotidiana del nostre entorn que podem observar com s'estan produint aquests canvis. Com es transformen alhora els missatges, els formats, les tecnologies i les capacitats.

Cal admetre que és relativament senzill veure aquestes transformacions des d'una òptica negativa. I, així, deduir que el cap ocupat per un doll excessiu de percepcions no pot pensar. I que, per tant, les lògiques i les categories es tornen confuses, i la persona esdevé menys lliure i menys capacitada.

En aquesta línia (i potser m'equivoco de mig a mig) sembla situar-se, per exemple, l'argumentació que observa en les conductes humanes contemporànies una progressiva agramaticalitat (com argumenta Duch [2OI2]). Davant de la lògica gramatical del discurs entès com a interacció social (de tot tipus de discursos, no solament el lingüístic, sinó el social, el corporal, el de la violència o el de gènere) provinent de la cultura antiga, dels grecs fins al segle Xx, la societat actual pot estar en un procés de «banalització de la paraula». I la rierada d'aquesta banalització es pot estar enduent tota una civilització de codis, de valors, d'organització social i de comportaments. Aquest tipus d'argumentació — al meu entendre massa apocalíptica - acostuma a ser ben rebuda en medis intel-lectuals. Sempre queda bé pensar en una elit suposadament conscient i ben informada que adverteix de l'amenaça que ens envaeix i que ens porta a una època de barbàrie (potser sense 
avaluar prou la barbàrie evident en què hem estat convivint durant tants segles de gramaticalitat i d'escriptura de les «classes educades»!).

Però faig referència a aquesta argumentació precisament per intentar de proposar alternatives. Jo crec que alguns intel-lectuals confonen la banalització de la paraula amb allò que en realitat és l'alba d'una nova comunicabilitat. Em poden qualificar d'optimista o d'il-lús, però els anys que he treballat amb joves estudiants em fan creure que segurament ells estan fent sorgir uns altres tipus de «gramaticalitat». No estan destruint el discurs lògic, sinó que estan jugant amb barreges d'altres lògiques. I que més enllà del soroll tecnològic que produeix la pressió mediàtica i comercial, alhora explorem vies noves que segurament s'allunyen molt de l'experiència i dels interessos del model clàssic d'intel-lectual, però que potser estan més adequadament sincronitzades amb els interessos de moltes persones del nostre entorn social.

Perdoneu que m'hagi allunyat massa, probablement, de la temàtica de la comunicació folklòrica, però la intenció és remarcar la riquesa de possibilitats que la nostra disciplina té al davant, i la immensitat del camp d'observació que tenim a l'abast. Si està sorgint tot un nou continent de sociabilitat i d'interaccions «cara a cara» mitjançades tecnològicament, potser nosaltres — armats amb les eines més clàssiques i més flexibles per a la comprensió d'aquestes interaccions- som dels investigadors socials més ben posicionats a l'hora de saber estudiar i escriure la crònica d'aquest sorgiment.

\section{Referències bibliogràfiques}

DuCH, Lluís (20I2): La banalització de la paraula. Barcelona: Centre de Cultura Contemporània de Barcelona.

GOFFMAN, Erwin (I967): Interaction ritual: essays on face-to-face behavior. Nova York: Anchor Books.

GOODY, Jack (I986): The logic of writing and the organization of society. Cambridge: Cambridge University Press.

Pujol, Josep M. (1985): «Literatura tradicional i etnopoètica: balanç d'un folklorista». Dins Dolors LlOPART; Joan PRAT; Llorenç PRATS: La cultura popular a debat. Barcelona: Altafulla, p. I58-I67. [Inclòs dins Carme OrIOL; Emili SAMPER (ed.) (20I3): Això era i no era. Obra folklòrica de Josep M. Pujol. Tarragona: Publicacions Universitat Rovira i Virgili, p. 25-33.]

Roviró, Ignasi (I992): «Aproximació a l'estudi de la comunicació folklòrica». Ausa núm. I28-I29 (I992): 7I-IO4. 